ENTREPRENEURSHIP AND SUSTAINABILITY ISSUES

ISSN 2345-0282 (online) http://jssidoi.org/jesi/ 2020 Volume 8 Number 1 (September) http://doi.org/10.9770/jesi.2020.8.1(5)

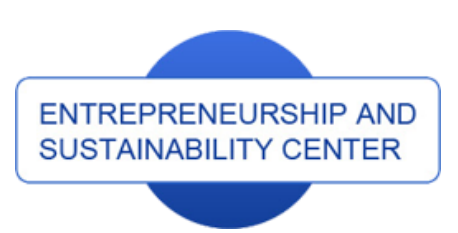

Publisher

http://jssidoi.org/esc/home

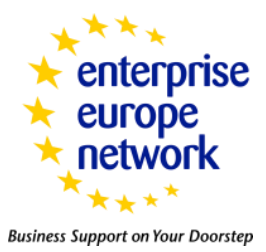

CASPA

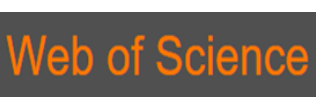

Clarivate
Analytics

\title{
EXPLORING BRAND LOYALTY TOWARD TRADITIONAL CONFECTIONERIES IN AN EMERGING MARKET
}

\author{
Nguyen Viet Thai ${ }^{1}$, Dang Hong Vuong ${ }^{2}$, Nguyen Thi Thu Ha ${ }^{3^{*}}$, Nguyen Quoc Thinh ${ }^{4}$, \\ Myeong Hwan Kim ${ }^{5}$, Nguyen Le Dinh Quy ${ }^{6 *}$ \\ ${ }^{1}$ Department of External Affairs and Communication, Thuongmai University, Hanoi, Vietnam. \\ ${ }^{2}$ Department of Finance - Banking and Business Administration, Quy Nhon University, Quy Nhon, Vietnam. \\ ${ }^{3}$ Faculty of Business Administration, Thuongmai University, Hanoi, Vietnam. \\ ${ }^{4}$ Faculty of Marketing, Thuongmai University, Hanoi, Vietnam. \\ ${ }^{5}$ Department of Economics and Finance, Purdue University Fort Wayne, Fort Wayne, USA. \\ ${ }^{6}$ VNUK Institute for Research and Executive Education, the University of Danang, Danang, Vietnam \\ $\begin{aligned} & \text { Email: }^{* *} \text { quy.nguyen@vnuk.edu.vn } \text { (Coressponding Author) } \\ & 3^{*} \text { nguyenthuha307@tmu.edu.vn (Co-coressponding author) }\end{aligned}$
}

Received 15 May 2020; accepted 26 July 2020; published 30 September 2020

\begin{abstract}
The purpose of this paper is to empirically explore the effects of brand dimensions, including brand image, brand value, brand impact, and brand satisfaction, on the brand loyalty of purchasers in an emerging country, Vietnam. The data were collected using paperbased surveys with a collected total of 310 responses from participants who had purchased traditional confectionery products. Structural Equation Modelling (SEM) was used to fully test the proposed hypotheses. The main findings reveal that brand image, brand impact, and brand satisfaction are important drivers of customers' brand loyalty. Among these brand dimensions, brand image is found to have the strongest effect on brand loyalty, while brand value had no impact on brand loyalty. Based on the findings, theoretical and practical implications are suggested for stakeholders, marketers, producers, and policymakers to build customer brand loyalty toward traditional confectioneries. Further research directions are also presented in this study.
\end{abstract}

Keywords: Traditional Confectioneries; Brand; Brand Loyalty; Customers; Structural Equation Modelling (SEM).

Reference to this paper should be made as follows: Thai, N.V., Vuong, D.H., Ha, N.T.T., Thinh, N.Q., Kim, M.H., Quy, N.1.D. 2020. Exploring brand loyalty toward traditional confectioneries in an emerging market. Entrepreneurship and Sustainability Issues, 60-72. http://doi.org/10.9770/jesi.2020.8.1(5)

JEL Classifications: J50, M31, M30 


\section{ENTREPRENEURSHIP AND SUSTAINABILITY ISSUES}

ISSN 2345-0282 (online) http://jssidoi.org/jesi/ 2020 Volume 8 Number 1 (September) http://doi.org/10.9770/jesi.2020.8.1(5)

\section{Introduction}

In 2018, the rate of Gross Domestic Product (GDP) growth of Vietnam recorded its highest level at 7.08\%, making the nation one of the top growing economies in the region and the world. The average nominal GDP per capita reached approximately US\$2,600 (GSO, 2019). Moreover, since the population ranks $14^{\text {th }}$ in the world (about 95 million), Vietnam became an enormous market for attracting various business investment, and is forecasted to be among the top 20 markets in the world by 2050 (GSO, 2019; PwCVietnam \& VCCI, 2019). Additionally, according to Nielsen (Nielse, 2019), Vietnam's Consumer Confidence Index score had the biggest gain in Asia Pacific, and became the third most confident country in the world, attributing to an increase in the purchasing power of customers, especially in the areas of food and beverages in this emerging country. In the food and beverage industry, revenue in the confectionery segment will amount to US\$1,355 million in 2020, and the average per capita consumption is expected to stand at $2.3 \mathrm{~kg}$ in 2020 (Statista, 2019). In Vietnam, confectionery consumption characteristics have a clear seasonal nature while the market gradually grows from the Mid-Autumn Festival to the Lunar New Year. During this period, consumers tend to purchase more traditional products such as mooncakes, candied lotus, coconut candy, squash, soursop, and green bean cakes from local brands such as King Do, Gia Bao, Bao Hien Rong Vang, or Bao Minh (VietnamNews, 2018). Therefore, the Vietnamese confectionery market is recognized as a precious production hub and dynamic consumer market with great potential for growth for confectionery producers. However, to compete with imported products from China, Thailand, Malaysia, or other global market players such as Orion, Lotte, Nestlé, or Mondelēz, domestic manufacturers should pay more attention to customers in terms of improving quality, packaging, marketing campaigns, and especially brand loyalty for traditional confectioneries that express the history and the marvelous culture of Vietnam.

A brand can be defined as a symbol or a name associated with tangible and emotional attributes in order to differentiate one producer's goods or services from rivals' goods (Aaker, 2013; Seetharaman et al., 2001). Given that the importance of brand multi-dimensions for products, determinants of brand loyalty toward traditional confectioneries have not yet been investigated in Vietnam. This paper, therefore, aims to explore the influence of brand image, brand impact, brand value, and brand satisfaction on brand loyalty toward these products in this developing market.

To be consistent with these objectives, this research is structured as follows. First, the theoretical background on brand dimensions and hypotheses are discussed in Section 2. This is followed by the development of a research model in Section 3. Next, the questionnaire and measures, sample and data collection, and data analysis methods are explained in Section 4. Afterward, results, discussion, and implications are provided in Section 5. Finally, the conclusion and limitations of the study and future research directions are presented in Section 6.

\section{Literature review and hypothesis development}

\subsection{Brand Image}

According to Keller (2013), brand image is considered a perceptual subjective phenomenon reflected through consumers' feelings for products due to their memories. Similarly, it can be also defined as buyers' feelings and thoughts about a brand (Roy \& Banerjee, 20078). Brand image has a multifunction of intangible and tangible features allowing customers to recognize a product (Bivainiené, 2007). In other words, brand image assists consumers in identifying their wants and needs with a brand. Moreover, it helps them distinguish the brand of one producer from others (Anwar et al., 2011). Therefore, brand image serves as an important marketing instrument in building brand impact and forming customer loyalty (Sweeney \& Swait, 2008). A study by Islam \& Rahman (2016) emphasized that the more an attractive brand image creates a positive brand impact, the better consumers will associate with that brand. Moreover, brand image will increase the value for consumers. In their study, 


\section{ENTREPRENEURSHIP AND SUSTAINABILITY ISSUES}

ISSN 2345-0282 (online) http://jssidoi.org/jesi/ 2020 Volume 8 Number 1 (September) http://doi.org/10.9770/jesi.2020.8.1(5)

Faircloth et al. (2001) determined brand value could be directly or indirectly promoted through brand image. Their results were echoed by other studies when it was proved that brand image positively impacted brand value in consumers' eyes (Chinomona et al., 2013; Puška et al., 2019; Puška et al., 2018).

Several studies on brand dimensions have confirmed the significant relationship between brand image and brand satisfaction (Chao et al., 2015; Davies et al., 2003). Brand image also has a positive influence on the brand loyalty of consumers (Chen \& Tseng, 2010; Ogba \& Tan, 2009; Puška et al., 2018; Tan et al., 2011). Likewise, Puška et al. (2019) asserted that brand image created a satisfying brand for consumers, entailing their brand loyalty. Hence, the following hypotheses are developed.

H1: Brand image will have a positive influence on the brand impact.

H2: Brand image will have a positive influence on the brand value.

H3: Brand image will have a positive influence on the brand satisfaction.

H4: Brand image will have a positive influence on brand loyalty.

\subsection{Brand impact}

According to Puška et al. (2019), brand impact refers to a psychological reaction that entails certain customer positive or negative feelings. Brand impact was determined to have a positive influence on the satisfaction of consumers (Mishra et al., 2016; Puška et al., 2019). Furthermore, Chaudhuri \& Holbrook (2001) and Bahadir et al. (2008) argued that firms can improve their brand value by enhancing the brand impact on consumers. Also, many studies are confirming the positive influence of brand impact on brand value (Bahadir et al., 2008; Puška et al., 2019).

Chaudhuri \& Holbrook (2001) concluded that brand impact was a key predictor of customer brand loyalty because when they feel joyful, affectionate, or happy with a brand, they show higher commitment to the brand. This finding was confirmed by other studies (Matzler et al., 2008; Park \& Kim, 2016; Puška et al., 2019). The following set of hypotheses are therefore proposed.

H5: Brand impact will have a positive influence on brand value.

H6: Brand impact will have a positive influence on brand satisfaction.

H7: Brand impact will have a positive influence on brand loyalty.

\subsection{Brand Value}

Bolton \& Drew (1991) defined brand value as the brand assessment of customers due to their perceptions of that brand. Brand makes a great contribution to the sustainable competitive advantages of a firm, and brand value is the foundation of what producers obtain (Kotler et al., 2014). Leroi et al. (2014) and Giovanis \& Athanasopoulou (2017) suggested two approaches in determining brand value: one-dimensional and multi-dimensional. The onedimensional approach is the understanding of the brand value comprising the price and the quality of the product the consumer receives. Meanwhile, a multi-dimensional approach is the understanding of consumers from multiple dimensions, including social, conditional emotional, functional, and epistemic (Sheth et al., 1991).

According to Cronin et al. (2000), there exists a significant relationship between brand satisfaction and brand value. It was stated that high perceived value leads to high satisfaction (Erciş et al., 2012). Moreover, the finding of a study conducted by Vranesevic \& Stancec (2003) determined that brand value assisted firms in gaining competitive advantages and maintaining relationships with customers. This research result was echoed by other studies (Huang et al., 2016; Lam \& Shankar, 2014; Pan et al., 2012; Puška et al., 2018; Taylor et al., 2004). Therefore, the following hypotheses emerge. 
H8: Brand value has a positive influence on brand satisfaction.

H9: Brand value has a positive influence on brand loyalty.

\subsection{Brand Satisfaction}

Satisfaction is defined as the fulfillment response of customers based upon the assessment that a service or product feature provides a pleasurable level of consumption (Oliver, 2010). In other words, it is defined as the cumulative satisfaction of the overall evaluation of customers based on the experience with a service, product brand, or actual purchase. Moreover, brand satisfaction plays a vital role in preserving brand value and retaining customers, resulting in brand selection (Puška et al., 2019). This finding is consistent with a study by Lai et al. (2009) wherein they stated that brand satisfaction was an indispensable requirement for customer repurchase intention. Hence, consumer satisfaction will affect brand loyalty once the image and value of such brands are considered (Jones \& Suh, 2000; Puška et al., 2018; Taylor et al., 2004; Veloutsou, 2015). Hence, we propose the following hypothesis.

H10: Brand satisfaction has a positive influence on brand loyalty.

\subsection{Brand Loyalty}

Brand loyalty is defined as the positive feelings of a customer toward a brand when he is ready to pay a higher price for that brand. Moreover, he tends to suggest that brand to other people (Giddens, 2002). Chaudhuri \& Holbrook (2001) stated that brand loyalty evoked a customer's preference for a certain brand over a while.

Brand loyalty consists of two factors, attitudinal and behavioral (Aaker, 2013). Behavioral loyalty explains the repeated buying of a brand over time, whereas attitudinal loyalty refers to a dispositional commitment based on particular preferences of some unique value associated with a brand (Chaudhuri \& Holbrook, 2001; Huang et al., 2015). In addition, according to Chaudhuri \& Holbrook (2001), brand loyalty is a decisive driver for a company's profitability and competitive advantages. Hence, every company desires to have strong brand loyalty (Morrison \& Crane, 2007).

Based on the above discussed theoretical background and hypothesis development, the following research model is proposed (Figure 1).

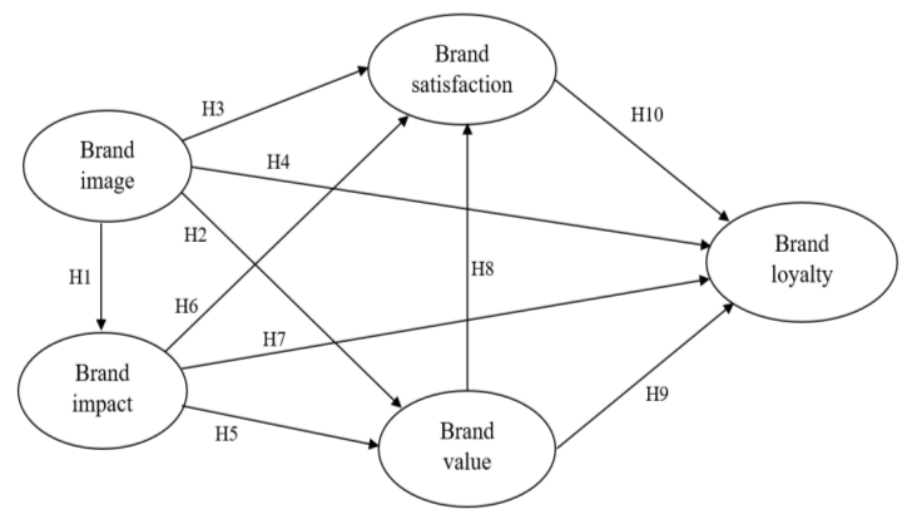

Figure 1. The proposed research model 


\section{Research methodology}

\subsection{Questionnaire and Measures}

Items for measuring the constructs in the proposed research model of this study are first identified (see Table 1). For the reliability and validity of the constructs, most items are adopted from previous studies and were carefully translated into Vietnamese based on the back-translation recommended by Behling \& Law (2000). To ensure the face validity of the measured items, two experts in brand development and two marketing scholars were invited to review the questionnaire. As most of the scales were taken from foreign research, a pilot survey of 20 samples was conducted to improve the wording, readability, clarity, and comprehensiveness of the questionnaire. Following comments and feedback from respondents, some items were amended. Specifically, 3 new items were suggested for the brand image construct. The final questionnaire comprised 23 items measuring 5 constructs, and is shown in Table 1. All the items were measured on a 5-point Likert scale ranging from 1 for 'strongly disagree' to 5 for 'strongly agree.'

For the brand image, a total of 5 items were used. Of these, 3 items regarding the flavor, nutrition value, and expiry date were self-developed according to the suggestions of the respondents, and 2 items were taken from Matzler et al. (2008) and Cho \& Fiore (2015). To measure the brand impact, 3 items were adopted from prior research conducted by Mishra \& Das (2016) and Chaudhuri \& Holbrook (2001), and the other item regarding pride from using a brand was recommended by the respondents. For the brand value, 4 items were taken from Giovanis \& Athanasopoulou (2017) and Nyadzayo \& Khajehzadeh (2016). To measure the brand satisfaction, 5 items were adopted from Kuikka \& Laukkanen (2012) and Nyffenegger et al. (2015). Finally, 4 brand royalty items were taken from prior studies by Chaudhuri and Holbrook (2001), Giovanis \& Athanasopoulou (2017), and Krystallis \& Chrysochou (2014).

Table 1: Constructs and items

\begin{tabular}{|c|c|c|}
\hline Construct & Question & Source \\
\hline $\begin{array}{l}\text { Brand } \\
\text { Image } \\
\text { (IMA) }\end{array}$ & $\begin{array}{l}\text { This traditional confectionery product has a unique and mild sweet flavor. } \\
\text { This traditional confectionery product has high nutritional value. } \\
\text { This traditional confectionery product has a fairly long shelf life. } \\
\text { This traditional confectionery product has an attractive appearance and color. } \\
\text { The quality of this traditional confectionery product is better than average. }\end{array}$ & $\begin{array}{l}\text { (Cho \& Fiore, 2015; } \\
\text { Matzler et al., 2008) }\end{array}$ \\
\hline $\begin{array}{l}\text { Brand } \\
\text { Impact } \\
\text { (IMP) }\end{array}$ & $\begin{array}{l}\text { This traditional confectionery brand makes me happy. } \\
\text { I feel good when I use this traditional confectionery brand. } \\
\text { This traditional confectionery brand gives me pleasure. } \\
\text { I feel proud to use this brand. }\end{array}$ & $\begin{array}{l}\text { (Chaudhuri \& } \\
\text { Holbrook, 2001; } \\
\text { Mishra et al., 2016) } \\
\text { Self-developed }\end{array}$ \\
\hline $\begin{array}{l}\text { Brand } \\
\text { Value } \\
\text { (VAL) }\end{array}$ & $\begin{array}{l}\text { The traditional confectionery brand justifies its price. } \\
\text { The quality of traditional confectionery brand justifies its price. } \\
\text { I get an excellent traditional confectionery brand concerning price. } \\
\text { My satisfaction is great concerning the price of this traditional confectionery brand. }\end{array}$ & $\begin{array}{l}\text { (Giovanis \& } \\
\text { Athanasopoulou, } \\
\text { 2017; Nyadzayo \& } \\
\text { Khajehzadeh, 2016) }\end{array}$ \\
\hline $\begin{array}{l}\text { Brand } \\
\text { Satisfaction } \\
\text { (SAT) }\end{array}$ & $\begin{array}{l}\text { I am pleased with this traditional confectionery brand. } \\
\text { I am content with this traditional confectionery brand. } \\
\text { I am always satisfied with this traditional confectionery brand. } \\
\text { The best ingredients are used in this traditional confectionery product. } \\
\text { Overall, I am satisfied with this traditional confectionery brand. }\end{array}$ & $\begin{array}{lr}\text { (Kuikka } & \& \\
\text { Laukkanen, } & 2012 ; \\
\text { Nyffenegger et } \\
2015)\end{array}$ \\
\hline
\end{tabular}


ENTREPRENEURSHIP AND SUSTAINABILITY ISSUES

ISSN 2345-0282 (online) http://jssidoi.org/jesi/

2020 Volume 8 Number 1 (September)

http://doi.org/10.9770/jesi.2020.8.1(5)

\begin{tabular}{|c|c|c|}
\hline $\begin{array}{l}\text { Brand } \\
\text { Loyalty } \\
\text { (LOY) }\end{array}$ & $\begin{array}{l}\text { I will purchase this traditional confectionery brand the next time I purchase a } \\
\text { confectionery product. } \\
\text { I intend to continuously purchase this traditional confectionery brand. } \\
\text { I will be willing to pay a higher price for this traditional confectionery brand over } \\
\text { other brands. } \\
\text { I will recommend this traditional confectionery brand to my friends. }\end{array}$ & $\begin{array}{lr}\text { (Chaudhuri } & \& \\
\text { Holbrook, 2001; } \\
\text { Giovanis } \quad \& \\
\text { Athanasopoulou, } \\
\text { 2017; Krystallis \& } \\
\text { Chrysochou, 2014) }\end{array}$ \\
\hline
\end{tabular}

\subsection{Sample and data collection}

Respondents participating in this research were Vietnamese aged 18 or over who had purchased traditional confectionery products. Paper-based surveys were utilized in order to collect data from nine confectionery stores in cities in the North Central and Central coastal areas of Vietnam (e.g. Hue, Da Nang, Quang Binh, and Khanh Hoa). With a population of more than 20 million, ranking $2^{\text {nd }}$ in Vietnam (GSO, 2018), along with royalty purchasing characteristics of customers (Thanh \& Huong, 2016), these areas are relevant and eligible to investigate brand loyalty for traditional confectionery products.

Convenience sampling was used, and the data collection period lasted 2 months from November 2019 to January 2020. A total number of 450 surveys were distributed (50 at each store). Of these, 425 surveys were returned. After eliminating surveys with unanswered items, invalid responses, and outliners, 310 usable responses were used for further analysis. The sample profile is illustrated in Table 2.

\section{Data Analysis Method}

As suggested by Kline (2010), a Structural Equation Modelling (SEM) should be used to analyze the complicated path model. This analysis technique has also been widely adopted in empirical research that investigated the antecedents of customer brand loyalty (Rahi et al., 2017; Soomro, 2019). Following suggestions by Anderson \& Gerbing (1988), SEM involves two stages of analysis, including a confirmatory factor analysis (CFA) and a structural model evaluation. CFA is meant to assess the validity of constructs and measurement in the proposed research model in terms of having good indicator loadings, composite reliability (CR), convergent validity, and discriminant validity. Structural model evaluation is then used to test the hypotheses. In SEM, some commonlyapplied fit indices, including the chi-square to degree-of-freedom ratio ( $\left.\chi^{2} / \mathrm{df}\right)$, goodness-of-fit index (GFI), comparative fit index (CFI), adjusted goodness-of-fit index (AGFI), Tucker and Lewis index (TLI), and root mean square error of approximation (RMSEA) are used to test the goodness-of-fit (GOF) of the measurement and structural models. According to Henry \& Stone (1994) and Hair et al. (2014), a model fit is reasonably confirmed to be good when $\chi 2 / \mathrm{df}$ is less than 3 , the values of GFI, AGFI, CFI, TLI are greater than 0.90, and RMSEA is less than 0.08 .

\section{Results}

\subsection{Sample Profile}

Among 310 respondents, approximately 63 percent were female. Concerning age, 26.1 percent were under 25, and 63.2 percent were aged 26-40. The respondents were quite educated; 25.2 percent held a college degree, and 39.3 held a bachelor's or master's degree. A majority of the respondents were employed and were students, accounting for 55.5 percent and 30.3 percent, respectively. Notably, in terms of monthly disposable income, 39 percent of respondents saw earnings of US\$ 251-500 per month and were indicated to be middle class in Vietnam, accounting for 40 percent of the entire population by income (Thanh \& Huong, 2016). Therefore, it is reasonable 
to assert that the sample in this study can represent the entire population of Vietnam. Furthermore, 64.8 percent of respondents reported that they lived in a family of 5 members and more (see Table 2).

Table 2: Demographic profile of the respondents

\begin{tabular}{|c|c|c|c|}
\hline \multicolumn{2}{|c|}{ Demographic Characteristics } & \multirow{2}{*}{$\begin{array}{l}\text { Frequency } \\
195\end{array}$} & \multirow{2}{*}{$\begin{array}{l}\text { Percentage } \\
62.9\end{array}$} \\
\hline & 1. Female & & \\
\hline Gender & 2. Male & 115 & 37.1 \\
\hline \multirow{4}{*}{ Age of Respondent } & 1. Under 25 & 81 & 26.1 \\
\hline & 2. $26-30$ & 116 & 37.4 \\
\hline & 3. $31-40$ & 80 & 25.8 \\
\hline & 4. 41 or Above & 33 & 10.6 \\
\hline \multirow{5}{*}{ Education Level } & 1. Common & 61 & 19.7 \\
\hline & 2. High School Degree & 49 & 15.8 \\
\hline & 3. College Degree & 78 & 25.2 \\
\hline & 4. University Degree & 98 & 31.6 \\
\hline & 5. Postgraduate & 24 & 7.7 \\
\hline \multirow{4}{*}{ Employment Status } & 1. Student & 94 & 30.3 \\
\hline & 2. Employed & 172 & 55.5 \\
\hline & 3. Unemployed & 25 & 8.1 \\
\hline & 4. Pensioner & 19 & 6.1 \\
\hline \multirow{5}{*}{ Income in US\$ } & 1. Under 250 & 101 & 32.6 \\
\hline & 2. $251-500$ & 121 & 39.0 \\
\hline & 3. $501-750$ & 59 & 19.0 \\
\hline & 4. $751-1000$ & 25 & 8.1 \\
\hline & 5. Over 1001 & 4 & 1.3 \\
\hline \multirow{4}{*}{$\begin{array}{l}\text { Number of Household } \\
\text { Members }\end{array}$} & $1.1-2$ & 49 & 15.8 \\
\hline & 2. $3-4$ & 60 & 19.4 \\
\hline & $3.5-6$ & 120 & 38.7 \\
\hline & 4. 7 or more & 81 & 26.1 \\
\hline
\end{tabular}

\subsection{Reliability and Validity}

The results of the multiple fit indices gained from Confirmatory Factor Analysis fulfilled the rule of thumb and all the resultant statistics satisfied the suggested levels $($ Chi-square $=303.433 ; \mathrm{df}=198 ; p<0.001 ; \chi 2 / \mathrm{df}=1.532$; $\mathrm{GFI}=0.923 ; \mathrm{AGFI}=0.901 ; \mathrm{CFI}=0.966 ; \mathrm{TLI}=0.960 ; \mathrm{RMSEA}=0.042$ ). Therefore, the sample data can be concluded to fit the model.

The results of the descriptive analysis in Table 3 demonstrated that brand value received the highest mean score $(\mathrm{M}=3.479)$, whilst respondents at least agreed with the statements within the brand image construct $(\mathrm{M}=3.117)$. To access the internal consistency of each construct, Cronbach's alpha $(\alpha)$ was calculated. It is suggested that the common acceptable threshold level for $\alpha$ value should be greater than 0.7 (Hair et al., 2014). The results illustrated in Table 3 showed that all the constructs' $\alpha$ values, ranging from 0.804 to 0.867 , indicate good reliability. 
Table 3: Descriptive statistics and reliability and convergent validity

\begin{tabular}{llll}
\hline Construct & Mean & Standard Deviation & Cronbach's Alpha \\
\hline Brand Image & 3.117 & 0.573 & 0.867 \\
Brand Impact & 3.341 & 0.583 & 0.804 \\
Brand Value & 3.479 & 0.592 & 0.825 \\
Brand Satisfaction & 3.394 & 0.586 & 0.862 \\
Brand Loyalty & 3.399 & 0.642 & 0.846 \\
\hline
\end{tabular}

As suggested by Fornell \& Larcker (1981) and Hair et al. (2014), convergent and discriminant validities were calculated to test construct validity. To examine convergent validity, we examined standardized factor loadings (FLs), composite reliability (CR), and the average variance extracted (AVE). As shown in Table 4, the relevant data had strong convergent validity when all FLs were greater than 0.5; CR was from 0.804 to 0.868 , and AVE exceeded 0.5 .

In order to test discriminant validity, the squared root of AVE for each construct was compared to its crosscorrelation with other constructs. All AVE scores exceeded the inter-construct correlation, satisfying the criteria to establish discriminant validity in this study (Table 4).

Table 4: Convergent validity and discriminant validity

\begin{tabular}{lllllllll}
\hline Construct & FLs & CR & AVE & IMA & IMP & VAL & SAT & LOY \\
\hline IMA & $0.667-0.795$ & 0.868 & 0.568 & $\mathbf{0 . 7 4 5}$ & & & & \\
IMP & $0.642-0.732$ & 0.804 & 0.506 & 0.279 & $\mathbf{0 . 7 1 1}$ & & & \\
VAL & $0.564-0.877$ & 0.808 & 0.521 & 0.291 & 0.251 & $\mathbf{0 . 7 2 2}$ & 0.427 & $\mathbf{0 . 7 5 0}$ \\
SAT & $0.617-0.846$ & 0.865 & 0.562 & 0.342 & 0.317 & 0.571 & $\mathbf{0 . 7 7 0}$ \\
LOY & $0.576-0.899$ & 0.853 & 0.593 & 0.537 & 0.475 & 0.285 & 0.571 \\
\hline
\end{tabular}

\section{Hypothesis Testing}

The structural model was applied to test ten proposed hypotheses. The results of hypothesis testing are shown in Table 5. The results showed a good model fit when the GOF indices were Chi-square $=285.542 ; \mathrm{df}=197 ; p<$ 0.001; $\chi 2 / \mathrm{df}=1.449 ; \mathrm{GFI}=0.927$; AGFI $=0.907 ; \mathrm{CFI}=0.971 ; \mathrm{TLI}=0.966$; and RMSEA $=0.038$. Specifically, $51.90 \%$ of the variance of traditional confectionery brand loyalty was predicted in this model (see Table 5). 


\section{ENTREPRENEURSHIP AND SUSTAINABILITY ISSUES}

ISSN 2345-0282 (online) http://jssidoi.org/jesi/

2020 Volume 8 Number 1 (September)

http://doi.org/10.9770/jesi.2020.8.1(5)

Table 5: Hypotheses testing and results

\begin{tabular}{|c|c|c|c|c|c|c|c|c|}
\hline H\# & \multicolumn{3}{|c|}{ Hypothesis Testing } & B & S.E. ${ }^{\dagger}$ & $t$-Value & $p$-Value & Results \\
\hline H1 & Brand Image & $\rightarrow$ & Brand Impact & 0.316 & 0.079 & 4.011 & $* * *$ & Supported \\
\hline $\mathrm{H} 2$ & Brand Image & $\rightarrow$ & Brand Value & 0.417 & 0.093 & 4.486 & $* * *$ & Supported \\
\hline H3 & Brand Image & $\rightarrow$ & Brand Satisfaction & 0.150 & 0.076 & 1.969 & $* *$ & Supported \\
\hline $\mathrm{H} 4$ & Brand Image & $\rightarrow$ & Brand Loyalty & 0.378 & 0.073 & 5.154 & $* * *$ & Supported \\
\hline H5 & Brand Impact & $\rightarrow$ & Brand Value & 0.081 & 0.080 & 1.008 & 0.314 & Rejected \\
\hline H6 & Brand Impact & $\rightarrow$ & Brand Satisfaction & 0.210 & 0.065 & 3.200 & $* *$ & Supported \\
\hline H7 & Brand Impact & $\rightarrow$ & Brand Loyalty & 0.269 & 0.063 & 4.294 & $* * *$ & Supported \\
\hline H8 & Brand Value & $\rightarrow$ & Brand Satisfaction & 0.391 & 0.080 & 4.919 & $* * *$ & Supported \\
\hline H9 & Brand Value & $\rightarrow$ & Brand Loyalty & 0.029 & 0.062 & 0.469 & 0.639 & Rejected \\
\hline H10 & Brand Satisfaction & $\rightarrow$ & Brand Loyalty & 0.361 & 0.074 & 4.902 & $* * *$ & Supported \\
\hline
\end{tabular}

Note: $* * * p<0.001 ; * * p<0.05 ;{ }^{* *}$ and ${ }^{* * *}$ denote statistically significant at the levels of $5 \%$ and $1 \%$, respectively. ${ }^{\dagger}$ Standard Error.

Regarding path analyses, eight proposed hypotheses were supported; however, the other two were rejected. Notably, all four paths starting from brand image directly influenced brand impact $(\beta=0.316, p<0.001)$, brand value $(\beta=0.417, p<0.001)$, brand satisfaction $(\beta=0.150, p<0.05)$, and brand loyalty $(\beta=0.378, p<0.001)$. Hence, hypotheses 1, 2, 3, and 4 were supported. Moreover, the relationship between brand impact and brand value was insignificant $(\beta=0.081), p>0.05)$. Subsequently, the relation path between brand value and brand loyalty was also insignificant. Due to these results, hypotheses 5 and 9 were rejected. Brand impact and brand value had a positive and significant influence on brand satisfaction $(\beta=0.210, p<0.05$ and $\beta=0.391, p<0.001$ respectively) in support of hypotheses 6 and 8 . Both relation paths, including brand value and brand satisfaction $(\beta=0.391, p<0.001)$, and brand satisfaction and brand loyalty $(\beta=0.361, p<0.001)$, were also found to be positive and significant, thus supporting hypotheses 8 and 10 .

\section{Discussion and implications}

The purpose of our study was to assess which determinants influenced brand loyalty toward tradetional confectionery products in Vietnam. Accordingly, the study proposed and tested a model combining brand multidimensions. Our findings have significant implications for both theory and practice.

Brand satisfaction was proven to have a greater positive and significant effect on customer brand loyalty than brand impact. This finding contradicts previous research (Hsieh \& Li, 2008). However, it supports studies by Zahorik \& Rust (1993) and Puška et al. (2018). Surprisingly, the findings of the study revealed that brand value has an insignificant influence on brand loyalty. Its indirect effect on brand loyalty is mediated by brand satisfaction. This finding echoes earlier research (Al-Msallam, 2015; Alhaddad, 2014; Elsäßer \& Wirtz, 2017). However, brand impact has the biggest significant influence on brand satisfaction, rather than brand image and brand impact. This finding demonstrates that consumers satisfied with a brand will make greater contributions to increase brand loyalty. Hence, traditional confectionery manufacturers in Vietnam should find measures and strategies in regard to making customers truly satisfyed.The results also revealed that brand image is a key driver of brand impact and has the biggest contribution to the formation of the brand loyalty of consumers. The finding is consistent with past research when it is concluded that a positive brand image will help to build brand loyalty (Hsieh \& Li, 2008; Nyadzayo \& Khajehzadeh, 2016). In emerging countries like Vietnam, the confectionery industry is highly competitive. Accordingly, traditional confectionery producers have to make every effort to diversify types and flavors, along with innovating packaging and investing, in building a widespread distribution 


\section{ENTREPRENEURSHIP AND SUSTAINABILITY ISSUES}

ISSN 2345-0282 (online) http://jssidoi.org/jesi/ 2020 Volume 8 Number 1 (September) http://doi.org/10.9770/jesi.2020.8.1(5)

system to meet the taste, convenience, and ease of purchase expectations of consumers. Furthermore, because most traditional confectioneries are produced by small branded establishments in regions across the nation, confectionery associations should be established in order to orient, direct, and create favorable conditions and a legal corridor for traditional confectionery producers to promote their brand images. Also, more and more Vietnamese customers pay attention to food safety issues (H. V. Nguyen et al., 2019; T. T. H. Nguyen et al., 2019), so traditional confectionery manufacturers must meet all food safety requirements as it directly affects consumer health. They should have a certificate of eligibility for food safety and apply standards of food hygiene and safety, such as ISO 9000 or ISO 22000. Further, because of the increasing consciousness about the sugar intake of customers, more sugar-free, organic, and low-calorie products with high nutritional value should be offered. Specifically, taking full advantage of unique, traditional confectioneries made completely with natural ingredients originating from Vietnam, the "Vietnamese people give priority to using Vietnamese goods" campaign should be often promoted in provinces and localities to propagate and stimulate patriotism so that traditional confectioneries are not only common products but also gifts of Vietnam's traditional flavors in diplomatic rituals, receptions, or meetings.

\section{Conclusion and further study}

This research is one of the first studies investigating the influence of the multi-dimensions of brand on brand loyalty toward traditional confectioneries in emerging countries like Vietnam. The results of the study showed that brand image affects brand loyalty more than brand impact and brand satisfaction. Therefore, it can be concluded that manufacturers of traditional confectioneries should invest more in developing the quality of products and innovating packaging to attract and satisfy customers. In addition, brand promotion and development campaigns should often be promoted in provinces nationwide.

Despite the significance of its findings, the study has several caveats. First of all, the study only investigated a sample in an emerging country, which may affect the generalizability of the results since the preferred type of confectioneries often differ according to differences in regulatory norms, cultures, tastes, and preferences of customers. Future research may consider a comparative analysis of brand loyalty toward traditional confectioneries among various countries to identify similarities and differences in brand loyalty. While this is consistent with numerous prior studies, future research is recommended to include the actual purchases of traditional confectionery purchasers. Finally, future studies may examine the moderating influence of individual variables such as ages, gender, lifestyle, and education on brand loyalty.

\section{Limitation}

This paper still has some limitations:

- The scale is still limited in many aspects, it is necessary to add demographic characteristics to find the relationship between these factors with each other. This is also a direction for further research.

- The sample is still quite small so the reliability is certain, so the results are not very comprehensive. 


\section{ENTREPRENEURSHIP AND SUSTAINABILITY ISSUES}

ISSN 2345-0282 (online) http://jssidoi.org/jesi/ 2020 Volume 8 Number 1 (September) http://doi.org/10.9770/jesi.2020.8.1(5)

\section{References}

Algharabat, R., Rana, N. P., Alalwan, A. A., Baabdullah, A., \& Gupta, A. (2020). Investigating the antecedents of customer brand engagement and consumer-based brand equity in social media. Journal of Retailing and Consumer Services, 53. https://doi.org/10.1016/j.jretconser.2019.01.016

Al-Msallam, S. (2015). Customer satisfaction and brand loyalty in the hotel industry. International Journal of Management Sciences and Business Research, 1, 232-251. https://papers.ssrn.com/sol3/Delivery.cfm/SSRN_ID2738998_code1825786.pdf?abstractid=2738998\&mirid=1

Anderson, J. C., \& Gerbing, D. W. (1988). Structural equation modeling in practice: A review and recommended two-step approach. Psychological Bulletin, 103(3), 411-423. http://www.personal.psu.edu/jxb14/M554/articles/Anderson\&Gerbing1988.pdf

Anwar, A., Gulzar, A., Sohail, F. B., \& Akram, S. N. (2011). Impact of brand image, trust and affect on consumer brand extension attitude: the mediating role of brand loyalty. International Journal of Economics and Management Sciences, 1(5), 73-79. https://www.researchgate.net/profile/Amir_Gulzar3/publication/285483638_Impact_of_brand_image_trust_and_affect_on_consumer_bran d_extension_attitude_The_mediating_role_of_brand_loyalty/links/5a8c6346458515a4068ada0e/Impact-of-brand-image-trust-and-affecton-consumer-brand-extension-attitude-The-mediating-role-of-brand-loyalty.pdf

Bapat, D. (2020). Examining the antecedents and consequences of brand experience dimensions: implications for branding strategy. Journal of Asia Business Studies. https://doi.org/10.1108/JABS-01-2019-0020

Bahadir, S. C., Bharadwaj, S. G., \& Srivastava, R. K. (2008). Financial value of brands in mergers and acquisitions: is value in the eye of the beholder? Journal of Marketing, 72(6), 49-64. https://ink.library.smu.edu.sg/cgi/viewcontent.cgi? $\operatorname{article=5132\& context=lkcsb\_ research}$

Bolton, R. N., \& Drew, J. H. (1991). A longitudinal analysis of the impact of service changes on customer attitudes. Journal of Marketing, 55(1), 1-9. http://www.academia.edu/download/31879294/survice_MKT..pdf

Chao, R.F., Wu, T.C., \& Yen, W.T. (2015). The Influence of Service Quality, Brand Image, and Customer Satisfaction on Customer Loyalty for Private Karaoke Roomsin Taiwan. The Journal of Global Business Management, 11(1), 59-67. http://www.jgbm.org/page/7\%20Tai-Chi\%20Wu.pdf

Chaudhuri, A., \& Holbrook, M. B. (2001). The chain of effects from brand trust and brand affect to brand performance: the role of brand loyalty. Journal of Marketing, 85(2), http://www.academia.edu/download/62807609/The_Chain_of_Effects_from_Brand_Trust_and_Brand_Affect_to_Brand_Performance_The Role of 20200403-127418-1wozu3e.pdf

Cho, E., Fiore, A. M., \& Russell, D. W. (2015). Validation of a fashion brand image scale capturing cognitive, sensory, and affective associations: Testing its role in an extended brand equity model. Psychology \& Marketing, 32(1), 28-48. https://doi.org/10.1002/mar.20762

GSO. (2019). Press release on socio-economic situation in the fourth quarter and in the year of $2019 . \quad$ Retrieved from https://www.gso.gov.vn/default_en.aspx?tabid=622\&ItemID=19144

Giovanis, A., Athanasopoulou, P., \& Tsoukatos, E. (2015). The role of service fairness in the service quality-relationship quality-customer loyalty chain. Journal of Service Theory and Practice. https://doi.org/10.1108/JSTP-11-2013-0263

Hsieh, A. T., \& Li, C. K. (2008). The moderating effect of brand image on public relations perception and customer loyalty. Marketing Intelligence \& Planning, 26(1), 26-42. http://192.192.107.208/FileUpload/upfile/020322042200834141612moderate\%20image.pdf

Krystallis, A., \& Chrysochou, P. (2014). The effects of service brand dimensions on brand loyalty. Journal of Retailing and Consumer Services, 21(2), 139-147. https://doi.org/10.1016/j.jretconser.2013.07.009

Kuikka, A., \& Laukkanen, T. (2012). Brand loyalty and the role of hedonic value. Journal of product \& brand Management, 21(7), 529 537. https://doi.org/10.1108/10610421211276277 


\section{ENTREPRENEURSHIP AND SUSTAINABILITY ISSUES}

ISSN 2345-0282 (online) http://jssidoi.org/jesi/ 2020 Volume 8 Number 1 (September) http://doi.org/10.9770/jesi.2020.8.1(5)

Lai, F., Griffin, M., \& Babin, B. J. (2009). How quality, value, image, and satisfaction create loyalty at a Chinese telecom. Journal of business research, 62(10), 980-986. https://doi.org/10.1016/j.jbusres.2008.10.015

Lam, S. Y., \& Shankar, V. (2014). Asymmetries in the effects of drivers of brand loyalty between early and late adopters and across technology generations. Journal of Interactive Marketing, 28(1), 26-42. https://doi.org/10.1016/j.intmar.2013.06.004

Leroi-Werelds, S., Streukens, S., Brady, M. K., \& Swinnen, G. (2014). Assessing the value of commonly used methods for measuring customer value: a multi-setting empirical study. Journal of the academy of marketing science, 42(4), 430-451. https://doi.org/10.1007/s11747-013-0363-4

Matzler, K., Grabner-Kräuter, S., \& Bidmon, S. (2008). Risk aversion and brand loyalty: the mediating role of brand trust and brand affect. Journal of Product \& Brand Management, 17(3), 154-162. https://doi.org/10.1108/10610420810875070

Mishra, M. K., Kesharwani, A., \& Das, D. (2016). The relationship between risk aversion, brand trust, brand affect and loyalty. Journal of Indian Business Research, 8(2), 78-97. https://doi.org/10.1108/JIBR-04-2015-0045

Morrison, S., \& Crane, F. G. (2007). Building the service brand by creating and managing an emotional brand experience. Journal of Brand Management, 14(5), 410-421. https://doi.org/10.1057/palgrave.bm.2550080

Nguyen, H. V., Nguyen, N., Nguyen, B. K., Lobo, A., \& Vu, P. A. (2019). Organic food purchases in an emerging market: The influence of consumers' personal factors and green marketing practices of food stores. International Journal of Environmental Research and Public Health, 16(6), 1037. https://doi.org/10.3390/ijerph16061037

Nyadzayo, M. W., \& Khajehzadeh, S. (2016). The antecedents of customer loyalty: A moderated mediation model of customer relationship management quality and brand image. Journal of Retailing and Consumer Services, 30, 262-270. https://doi.org/10.1016/j.jretconser.2016.02.002

Nyffenegger, B., Krohmer, H., Hoyer, W. D., \& Malaer, L. (2015). Service brand relationship quality: hot or cold?. Journal of Service Research, 18(1), 90-106. https://doi.org/10.1177/1094670514547580

Park, H., \& Kim, Y.-K. (2016). Proactive versus reactive apparel brands in sustainability: Influences on brand loyalty. Journal of Retailing and Consumer Services, 29, 114-122. https://doi.org/10.1016/j.jretconser.2015.11.013

Puška, A., Beganović, A., \& Popović Beganović, A. (2019). Consumers'loyalty toward dark chocolate. Ekonomska misao i praksa, 28(1), 245-266. https://hrcak.srce.hr/file/322677

Puška, A., Stojanović, I., \& Berbić, S. (2018). The impact of chocolate brand image, satisfaction, and value on brand loyalty. Economy \& Market Communication Review/Casopis za Ekonomiju i Trzisne Komunikacije, 8(1), 37-54. https://www.researchgate.net/publication/325929855_THE_IMPACT_OF_CHOCOLATE_BRAND_IMAGE_SATISFACTION_AND_V ALUE_ON_BRAND_LOYALTY

PwCVietnam, \& VCCI. (2019). Doing Business in Vietnam: A reference guide for entering the Vietnam market. Hanoi, Vietnam: PwC Vietnam. https://www.pwc.com/vn/en/publications/2019/pwc-vietnam-dbg-2019.pdf

Quy, N. L. D. (2020). An Overview of the Relationship between Psychological Capital and Entrepreneurial Orientation of Startup Companies. VNU Journal of Science: Policy and Management Studies, 36(1).

https://doi.org/10.25073/2588-1116/vnupam.4206

Rahi, S., Abd Ghani, M., \& Alnaser, F. M. (2017). The influence of e-customer services and perceived value on brand loyalty of banks and internet banking adoption: a structural equation model (SEM). The Journal of Internet Banking and Commerce, 22(1), 1-18. http://www.icommercecentral.com/open-access/the-influence-of-ecustomer-services-and-perceived-value-on-brand-loyalty-of-banks-andinternet-banking-adoption-a-structural-equation-model-sem.php?aid=85569

Soomro, Y. A. (2019). Antecedents of brand loyalty in the fashion industry of Pakistan: Moderating effect of Individual-level collectivist values. Journal of Organisational Studies and Innovation, 6(1), 33-46. https://mpra.ub.uni-muenchen.de/95356/1/MPRA paper 95356.pdf

Statista. (2019). Food Report 2018 - Confectionery. Retrieved from https://www.statista.com/study/48835/food-report-confectionery/ Sweeney, J., \& Swait, J. (2008). The effects of brand credibility on customer loyalty. Journal of Retailing and Consumer Services, 15(3), 179-193. https://doi.org/10.1016/j.jretconser.2007.04.001 


\section{ENTREPRENEURSHIP AND SUSTAINABILITY ISSUES}

ISSN 2345-0282 (online) http://jssidoi.org/jesi/ 2020 Volume 8 Number 1 (September) http://doi.org/10.9770/jesi.2020.8.1(5)

VietnamNews. (2018). VN confectionery products hold their own against foreign rivals. Retrieved from https://vietnamnews.vn/economy/422859/vn-confectionery-products-hold-their-own-against-foreign-rivals.html

Vraneševic, T., \& Stančec, R. (2003). The effect of the brand on perceived quality of food products. British Food Journal, 105(11), 811825. https://www.emerald.com/insight/content/doi/10.1108/00070700310511609/full/html

Nguyen Viet THAI work at Department of External Affairs and Communication, Thuongmai University, Hanoi, Vietnam. Email: thainv@tmu.edu.vn

ORCID ID: 0000-0003-3808-8274

Dang Hong VUONG work at Department of Finance - Banking and Business Administration, Quy Nhon University, Quy Nhon, Vietnam. Email: danghongvuong@qnu.edu.vn

ORCID ID: 0000-0002-7048-0834

Nguyen Thi Thu HA work at Faculty of Business Administration, Thuongmai University, Hanoi, Vietnam. Email: nguyenthuha307@tmu.edu.vn ORCID ID: 0000-0001-9775-0585

Nguyen Quoc THINH work at Faculty of Marketing, Thuongmai University, Hanoi, Vietnam. Email: thinh.nq@tmu.edu.vn ORCID ID: 0000-0001-7057-8965

Myeong Hwan KIM work at Department of Economics and Finance, Purdue University Fort Wayne, Fort Wayne, USA. Email: kimm@pfw.edu

ORCID ID: 0000-0003-4025-5051

Nguyen Le Dinh QUY work at VNUK Institute for Research and Executive Education, the University of Danang, Danang, Vietnam. Email: quy.nguyen@vnuk.edu.vn

ORCID ID: 0000-0002-2825-5924

Copyright (C) 2020 by author(s) and VsI Entrepreneurship and Sustainability Center

This work is licensed under the Creative Commons Attribution International License (CC BY).

http://creativecommons.org/licenses/by/4.0/

\section{c) (7) Open Access}

